\title{
Molecular Diversity of Giardia duodenalis, Cryptosporidium spp. and Blastocystis sp. in Asymptomatic School Children in Leganés, Madrid (Spain)
}

\author{
Aly Salimo Muadica ${ }^{1}$, Pamela Carolina Köster ${ }^{1}$, Alejandro Dashti ${ }^{1}$ (D) Begoña Bailo ${ }^{1}$ (D), \\ Marta Hernández-de-Mingo ${ }^{1}$, Lucia Reh ${ }^{1,2}$, Sooria Balasegaram ${ }^{3}$, Neville Q Verlander ${ }^{4}$, \\ Esther Ruiz Chércoles ${ }^{5}$ and David Carmena ${ }^{1, *(D)}$ \\ 1 Parasitology Reference and Research Laboratory, National Centre for Microbiology, Health Institute Carlos \\ III, Ctra. Majadahonda-Pozuelo Km 2, 28220 Majadahonda, Madrid, Spain; muadica@gmail.com (A.S.M.); \\ pamelakster@yahoo.com (P.C.K.); dashti.alejandro@gmail.com (A.D.); BEGOBB@isciii.es (B.B.); \\ martaher1@gmail.com (M.H.-d.-M.); LuciaReh@gmx.de (L.R.) \\ 2 European Program for Public Health Microbiology Training, European Centre for Disease Prevention and \\ Control, Gustav III:s Boulevard 40, 16973 Solna, Sweden \\ 3 Field Epidemiology Services, National Infection Service, Public Health England, Skipton House, 80 London \\ Road, London SE1 6LH, UK; Sooria.Balasegaram@phe.gov.uk \\ 4 d Statistics, Modelling and Economics Department, National Infection Service, Public Health England, \\ 61 Colindale Avenue, London NW9 5EQ, UK; Neville.Verlander@phe.gov.uk \\ 5 Health Care Centre María Jesús Hereza, Jesus Miguel Haddad Blanco 2, 28911 Leganés, Madrid, Spain; \\ eruizc@salud.madrid.org \\ * Correspondence: dacarmena@isciii.es; Tel.: +34-91-822-3641
}

Received: 8 February 2020; Accepted: 23 March 2020; Published: 25 March 2020

\begin{abstract}
Enteric parasites including Giardia duodenalis, Cryptosporidium spp., and to a lesser extent, Blastocystis sp. and Enterocytozoon bieneusi, are major worldwide contributors to diarrhoeal disease. Assessing their molecular frequency and diversity is important to ascertain the sources of infection, transmission dynamics, and zoonotic potential. Little molecular information is available on the genotypes of these pathogens circulating in apparently healthy children. Here, we show that asymptomatic carriage of G. duodenalis (17.4\%, 95\% CI: $15.5-19.4 \%)$, Blastocystis sp. (13.0\%, $95 \%$ CI: 11.4-14.8\%), and Cryptosporidium spp. (0.9\%, 95\% CI: $0.5-1.5 \%)$ is common in children (1-16 years; $n=1512$ ) from Madrid, Spain. Our genotyping data indicate that; (i) the observed frequency and diversity of parasite genetic variants are very similar to those previously identified in Spanish clinical samples, so that the genotype alone does not predict the clinical outcome of the infection, (ii) anthroponotic transmission accounts for a large proportion of the detected cases, highlighting that good personal hygiene practices are important to minimizing the risk of infection, (iii) Blastocystis ST4 may represent a subtype of the parasite with higher pathogenic potential, and (iv) Enterocytozoon bieneusi does not represent a public health concern in healthy children.
\end{abstract}

Keywords: Giardia; Cryptosporidium; Blastocystis; Enterocytozoon; asymptomatic children; PCR; molecular detection; molecular epidemiology; genotyping; Spain

\section{Introduction}

The enteric parasites Giardia duodenalis (Metamonada), Cryptosporidium spp. (Apicomplexa), Blastocystis sp. (Stramenopiles), and Enterocytozoon bieneusi (Microsporidia) are among the most frequent diarrheal pathogen affecting humans [1,2]. Transmission of these parasites occurs through 
the faecal-oral route, either directly from person-to-person or animal-to-person contact, or indirectly through contaminated water or food. Indeed, giardiosis and cryptosporidiosis are predominantly waterborne and foodborne, with outbreaks of both diseases commonly reported globally $[3,4]$. Not surprisingly, children living in unfavourable settings with poor sanitation and unsafe drinking water are particularly vulnerable to these infections.

Individuals infected by G. duodenalis, Cryptosporidium spp., Blastocystis sp., and E. bieneusi may develop a wide range of clinical manifestations ranging from asymptomatic, to acute or chronic diarrheal disease. Clinical signs include diarrhoea, nausea, and weight loss. Vomiting, blood in the stool, and fever are less common [2,5]. There is strong evidence demonstrating that childhood giardiosis and cryptosporidiosis have a strong link with growth and cognitive retardation and failure to thrive [6], even if infected individuals are asymptomatic [7]. Although these conditions have been more frequently reported in children in low-income countries, they have also been identified in industrialized countries, including Spain [8,9]. Additionally, Blastocystis sp. infections have been associated with intestinal (irritable bowel syndrome) and extra-intestinal (urticaria) disorders [10,11].

Although rarely a life-threatening condition, about 200 million people have symptomatic giardiasis only in low- and middle-income countries [12]. In contrast, acute Cryptosporidium infections are estimated to cause 48,000 annual deaths in children under five years old globally [13]. Regarding Blastocystis, more than 1 billion people carry the parasite worldwide [14], whereas E. bieneusi infection is regarded as an emerging public health concern both, in immunocompromised (e.g., HIV-infected patients and organ transplant recipients) patients, and immunocompetent individuals [15].

Giardia duodenalis, Cryptosporidium spp., Blastocystis sp., and E. bieneusi exhibit extensive intra-species genetic diversity, allowing several genotypes/subtypes to be identified that have marked differences in growth rate, drug susceptibility, host range, geographical distribution, and other biological features. Giardia duodenalis is indeed a multi-species complex comprising eight (A to $\mathrm{H}$ ) distinct assemblages, of which zoonotic assemblages A and B are commonly reported to infect humans [16]. Cryptosporidium encompasses at least 38 valid species, with C. hominis and C. parvum causing more than $90 \%$ of documented human cases of cryptosporidiosis [17]. At least 26 subtypes (ST) have been identified within Blastocystis sp. Among them, ST1-9 and ST12 have been reported in humans [18]. Finally, several hundred E. bieneusi genotypes have been defined and grouped in 11 phylogenetic groups. Group 1 and Group 2 include most of the potentially zoonotic genotypes, whereas the rest of the clusters display genotypes with strong host specificity [2].

It is now clear that most human infections from enteric parasites do not develop any symptoms $[19,20]$. This issue raises the question of whether pathogenicity and symptomatology may be associated, at least partially, with the parasite's genotype causing the infection [21-23]. In Spain, asymptomatic carriage of diarrhoea-causing enteric parasites has been mainly investigated in schoolchildren populations by conventional (microscopy examination, ELISA) methods [24-26]. Molecular-based surveys are far scarcer and restricted to relatively small sample sizes [27]. No information is currently available on the presence of E. bieneusi in non-clinical individuals. These studies revealed that asymptomatic carriage of G. duodenalis, Cryptosporidium spp., and Blastocystis sp. have been reported at largely varying ( 3 to $35 \%$ ) rates of infection, depending on the population and geographical area surveyed and the diagnostic method used. This PCR and sequencing-based study aims at investigating the occurrence and molecular diversity of G. duodenalis, Cryptosporidium spp., Blastocystis sp., and E. bieneusi in a large population of apparently healthy schoolchildren in central Spain.

\section{Materials and Methods}

\subsection{Ethics Approval and Consent to Participate}

This study has been approved by Ethics Committee of the Health Institute Carlos III on 23 October 2017 under the reference number CEI PI17_2017-v3. Informative meetings were held for interested 
families to explain the purpose of the study and the procedures involved. Written informed consent was obtained from parents or legal guardians of participating schoolchildren.

\subsection{Study Area and Stool Sample Collection}

A cross-sectional molecular epidemiological study of diarrhoea-causing enteric parasites including the protozoan Giardia duodenalis and Cryptosporidium spp., the stramenopile Blastocystis sp., and the microsporidia Enterocytozoon bieneusi was carried out in voluntary asymptomatic schoolchildren (3-16 years) in the Leganés municipality (southern metropolitan area of Madrid, central Spain) between November 2017 and June 2018. Stool samples were collected from participating schoolchildren attending 12 primary and secondary schools and their siblings (Figure 1). School features and sampling procedures were described in detail elsewhere [28]. Collected stool samples were transported to the Spanish National Centre for Microbiology and stored at $4{ }^{\circ} \mathrm{C}$ (1-5 days) or $-20^{\circ} \mathrm{C}$ (>5 days) without preservatives until further PCR testing.

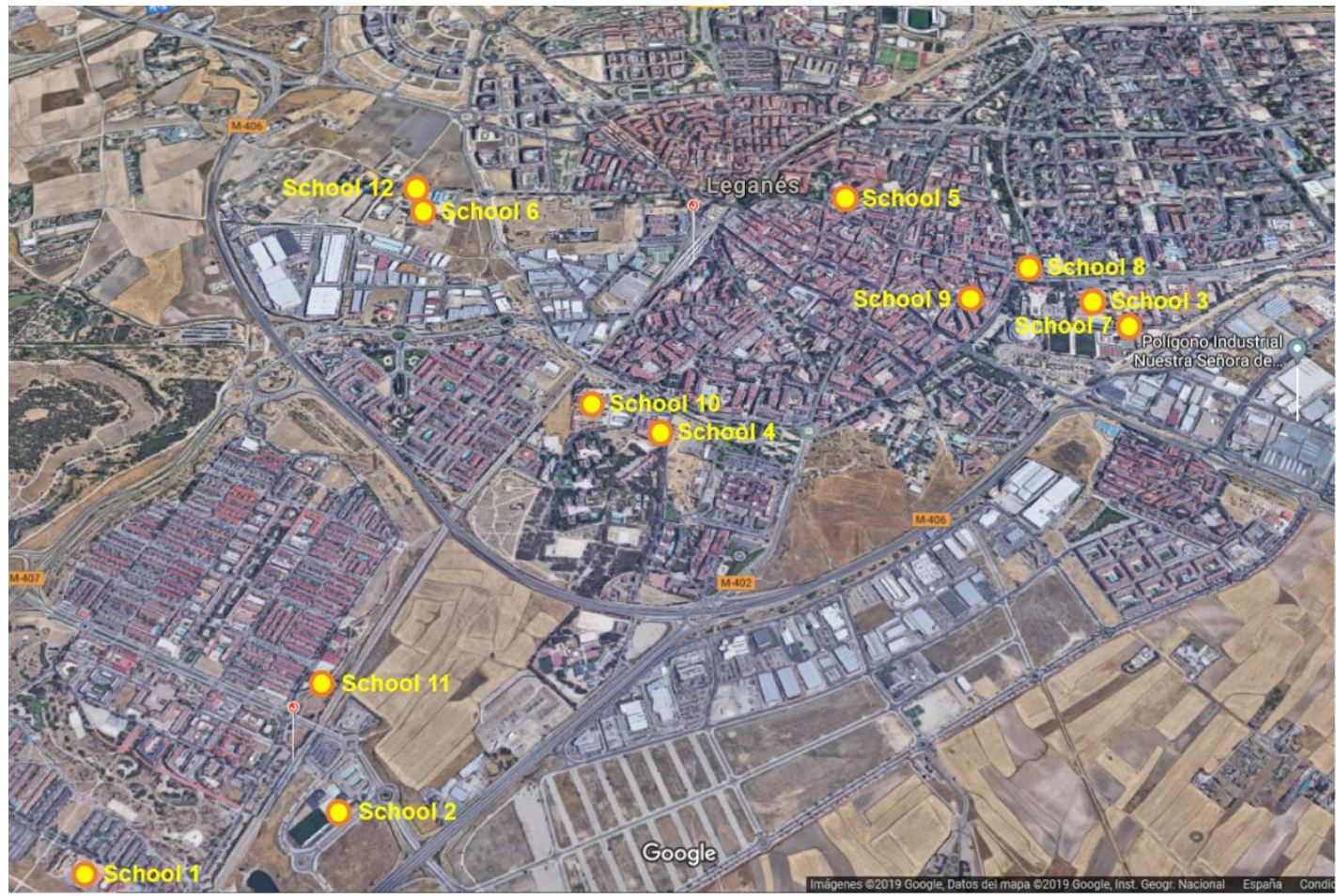

Figure 1. Aerial view of the Leganés municipality (southern metropolitan area of Madrid) indicating the exact geographical location of the 12 primary and secondary schools sampled in the present study.

\subsection{DNA Extraction and Purification}

Genomic DNA was isolated from about $200 \mathrm{mg}$ of each faecal specimen by using the QIAamp DNA Stool Mini Kit (Qiagen, Hilden, Germany) according to the manufacturer's instructions, except that samples mixed with InhibitEX buffer were incubated for $10 \mathrm{~min}$ at $95^{\circ} \mathrm{C}$. Extracted and purified DNA samples $(200 \mu \mathrm{L})$ were kept at $-20^{\circ} \mathrm{C}$ until further molecular analysis. A water extraction control was included in each sample batch processed.

\subsection{Molecular Detection and Characterization of Giardia duodenalis}

A qPCR protocol amplifying a $\sim 62 \mathrm{bp}$-fragment of the small subunit ribosomal RNA (ssu rRNA) gene of Giardia duodenalis was used as initial screening test for the presence of the parasite [29]. The multicopy ssu rRNA gene is one of the preferred loci for detection purposes due to its high diagnostic sensitivity. Amplification reactions $(25 \mu \mathrm{L})$ consisted of $3 \mu \mathrm{L}$ of template DNA, $0.5 \mu \mathrm{M}$ of 
primers Gd-80F and Gd-127R, $0.4 \mu \mathrm{M}$ of probe (Table S1), and $12.5 \mu \mathrm{L}$ TaqMan ${ }^{\circledR}$ Gene Expression Master Mix (Applied Biosystems, CA, USA). Detection of parasitic DNA was performed on a Corbett Rotor Gene ${ }^{\mathrm{TM}} 6000$ real-time PCR system (Qiagen) using an amplification protocol consisting on an initial hold step of $2 \mathrm{~min}$ at $55^{\circ} \mathrm{C}$ and $15 \mathrm{~min}$ at $95^{\circ} \mathrm{C}$ followed by 45 cycles of $15 \mathrm{~s}$ at $95^{\circ} \mathrm{C}$ and $1 \mathrm{~min}$ at $60^{\circ} \mathrm{C}$. Water (no-template) and genomic DNA (positive) controls were included in each PCR run.

Giardia duodenalis isolates with a qPCR-positive result were re-assessed by sequence-based multi-locus genotyping of the single-copy genes encoding for the glutamate dehydrogenase $(g d h)$, B-giardin ( $b g$ ) and triose phosphate isomerase (tpi) proteins of the parasite. A semi-nested PCR was used to amplify a $\sim 432$-bp fragment of the $g d h$ gene [30]. PCR reaction mixtures $(25 \mu \mathrm{L})$ included $5 \mu \mathrm{L}$ of template DNA and $0.5 \mu \mathrm{M}$ of the primer pairs GDHeF/GDHiR in the primary reaction and GDHiF/GDHiR in the secondary reaction (Table S1). Both amplification protocols consisted of an initial denaturation step at $95^{\circ} \mathrm{C}$ for $3 \mathrm{~min}$, followed by 35 cycles of $95^{\circ} \mathrm{C}$ for $30 \mathrm{~s}, 55^{\circ} \mathrm{C}$ for $30 \mathrm{~s}$ and $72{ }^{\circ} \mathrm{C}$ for $1 \mathrm{~min}$, with a final extension of $72{ }^{\circ} \mathrm{C}$ for $7 \mathrm{~min}$. A nested PCR was used to amplify a $\sim 511 \mathrm{bp}$-fragment of the $b g$ gene [31]. PCR reaction mixtures $(25 \mu \mathrm{L})$ consisted of $3 \mu \mathrm{L}$ of template DNA and $0.4 \mu \mathrm{M}$ of the primers sets G7_F/G759_R in the primary reaction and G99_F/G609_R in the secondary reaction (Table S1). The primary PCR reaction was carried out with the following amplification conditions: One step of $95^{\circ} \mathrm{C}$ for $7 \mathrm{~min}$, followed by 35 cycles of $95^{\circ} \mathrm{C}$ for $30 \mathrm{~s}, 65^{\circ} \mathrm{C}$ for $30 \mathrm{~s}$, and $72{ }^{\circ} \mathrm{C}$ for $1 \mathrm{~min}$ with a final extension of $72{ }^{\circ} \mathrm{C}$ for $7 \mathrm{~min}$. The conditions for the secondary PCR were identical to the primary PCR, except that the annealing temperature was $55^{\circ} \mathrm{C}$. Finally, a nested PCR was used to amplify a $\sim 530$ bp-fragment of the tpi gene [32]. PCR reaction mixtures $(50 \mu \mathrm{L})$ included 2-2.5 $\mu \mathrm{L}$ of template DNA and $0.2 \mu \mathrm{M}$ of the primer pairs AL3543/AL3546 in the primary reaction and AL3544/AL3545 in the secondary reaction (Table S1). Both amplification protocols consisted of an initial denaturation step at $94{ }^{\circ} \mathrm{C}$ for $5 \mathrm{~min}$, followed by 35 cycles of $94{ }^{\circ} \mathrm{C}$ for $45 \mathrm{~s}, 50^{\circ} \mathrm{C}$ for $45 \mathrm{~s}$ and $72{ }^{\circ} \mathrm{C}$ for $1 \mathrm{~min}$, with a final extension of $72{ }^{\circ} \mathrm{C}$ for $10 \mathrm{~min}$.

\subsection{Molecular Detection and Characterization of Cryptosporidium spp. Isolates}

The presence of Cryptosporidium spp. was assessed using a nested PCR to amplify a $~ 587-b p$ fragment of the $s s u \mathrm{rRNA}$ gene of the parasite [33]. Amplification reactions $(50 \mu \mathrm{L})$ included $3 \mu \mathrm{L}$ of DNA sample and $0.3 \mu \mathrm{M}$ of the primer pairs CR-P1/CR-P2 in the primary reaction and CR-P3/CPB-DIAGR in the secondary reaction (Table S1). Both PCR reactions were carried out as follows: One step of $94^{\circ} \mathrm{C}$ for $3 \mathrm{~min}$, followed by 35 cycles of $94{ }^{\circ} \mathrm{C}$ for $40 \mathrm{~s}, 50{ }^{\circ} \mathrm{C}$ for $40 \mathrm{~s}$ and $72{ }^{\circ} \mathrm{C}$ for $1 \mathrm{~min}$, concluding with a final extension of $72^{\circ} \mathrm{C}$ for $10 \mathrm{~min}$. Sub-typing of the isolates identified as $C$. hominis or $C$. parvum was attempted at the $60 \mathrm{kDa}$ glycoprotein (gp60) gene. Briefly, a nested PCR was conducted to amplify a $\sim 870$-bp fragment of the gp60 locus [34]. PCR reaction mixtures $(50 \mu \mathrm{L})$ included $2-3 \mu \mathrm{L}$ of template DNA and $0.3 \mu \mathrm{M}$ of the primer pairs AL-3531/AL-3535 in the primary reaction and AL-3532/AL-3534 in the secondary reaction (Table S1). The primary PCR reaction consisted of an initial denaturation step of $94{ }^{\circ} \mathrm{C}$ for $5 \mathrm{~min}$, followed by 35 cycles of $94^{\circ} \mathrm{C}$ for $45 \mathrm{~s}, 59^{\circ} \mathrm{C}$ for $45 \mathrm{~s}$, and $72{ }^{\circ} \mathrm{C}$ for $1 \mathrm{~min}$ with a final extension of $72{ }^{\circ} \mathrm{C}$ for $10 \mathrm{~min}$. The conditions for the secondary PCR were identical to the primary $\mathrm{PCR}$ except that the annealing temperature was $50^{\circ} \mathrm{C}$.

\subsection{Molecular Detection and Characterization of Blastocystis sp. Isolates}

Identification of Blastocystis sp. was achieved by a direct PCR targeting the ssu rRNA gene of the parasite [35]. This protocol uses the pan-Blastocystis, barcode primers RD5 and BhRDr (Table S1) to amplify a PCR product of $\sim 600 \mathrm{bp}$. Amplification reactions $(25 \mu \mathrm{L})$ included $5 \mu \mathrm{L}$ of template DNA and $0.5 \mu \mathrm{M}$ of the primer set RD5/BhRDr. Amplification conditions consisted of one step of $95^{\circ} \mathrm{C}$ for $3 \mathrm{~min}$, followed by 30 cycles of 1 min each at 94,59 and $72{ }^{\circ} \mathrm{C}$, with an additional 2 min final extension at $72{ }^{\circ} \mathrm{C}$. 


\subsection{Molecular Detection and Characterization of Enterocytozoon bieneusi Isolates}

Enterocytozoon bieneusi DNA was detected using a nested PCR to amplify a 390 bp-fragment of the entire internal transcribed spacer as well as portions of the flanking large and small subunits of the rRNA gene of the parasite [36]. Reaction mixtures $(50 \mu \mathrm{L})$ contained one $\mu \mathrm{L}$ of DNA template and $0.2 \mu \mathrm{M}$ of the primer pairs EBITS3/EBITS4 in the primary reaction and EBITS1/EBITS2.4 in the secondary reaction (Table S1). After denaturation at $94{ }^{\circ} \mathrm{C}$ for $3 \mathrm{~min}$, amplification conditions of the primary PCR included 35 cycles of amplification (denaturation at $94{ }^{\circ} \mathrm{C}$ for $30 \mathrm{~s}$, annealing at $57^{\circ} \mathrm{C}$ for $30 \mathrm{~s}$, and elongation at $72{ }^{\circ} \mathrm{C}$ for $40 \mathrm{~s}$ ), followed by a final extension at $72{ }^{\circ} \mathrm{C}$ for $10 \mathrm{~min}$. Conditions for the secondary PCR were identical to the primary PCR except only 30 cycles were carried out with an annealing temperature of $55^{\circ} \mathrm{C}$.

All samples were tested singly. Diagnostic sensitivities of the PCR-based methods used for the detection of G. duodenalis, Cryptosporidium spp., Blastocystis sp., and E. bieneusi were over 95\%. Diagnostic specificities were near $100 \%$ as most of the PCR-positive samples were confirmed by sequencing. All the direct, semi-nested, and nested PCR protocols described above were conducted on a 2720 thermal cycler (Applied Biosystems). Reaction mixes always included 2.5 units of MyTAQ ${ }^{\mathrm{TM}}$ DNA polymerase (Bioline $\mathrm{GmbH}$, Luckenwalde, Germany), and 5× MyTAQ ${ }^{\mathrm{TM}}$ Reaction Buffer containing $5 \mathrm{mM}$ dNTPs and $15 \mathrm{mM} \mathrm{MgCl}$. Laboratory-confirmed positive and negative DNA isolates for each parasitic species investigated were routinely used as controls and included in each round of PCR. PCR amplicons were visualized on 2\% D5 agarose gels (Conda, Madrid, Spain) stained with Pronasafe nucleic acid staining solution (Conda). Positive-PCR products were directly sequenced in both directions using the internal primer set described above. DNA sequencing was conducted by capillary electrophoresis using the BigDye ${ }^{\circledR}$ Terminator chemistry (Applied Biosystems) on an ABI PRISM 3130 automated DNA sequencer.

\subsection{Sequence and Phylogenetic Analyses}

Raw sequencing data in both forward and reverse directions were viewed using the Chromas Lite version 2.1 (Technelysium Pty Ltd., South Brisbane, Australia) sequence analysis program (https://technelysium.com.au/wp/chromas/). The BLAST tool (http://blast.ncbi.nlm.nih.gov/Blast.cgi) was used to compare nucleotide sequences with sequences retrieved from the NCBI GenBank database. Generated DNA consensus sequences were aligned to appropriate reference sequences using the MEGA version 6 software [37] to identify Giardia species and assemblages/sub-assemblages and Cryptosporidium species. Blastocystis sequences were submitted at the Blastocystis 18S database (http: //pubmlst.org/blastocystis/) for sub-type confirmation and allele identification. The sequences obtained in this study have been deposited in GenBank under accession numbers MN844134-MN844151 (G. duodenalis), MN836820-MN836825 (Cryptosporidium spp.) and MN836826-MN836842 (Blastocystis sp.).

\section{Results}

\subsection{Occurrence of Enteric Parasites}

During the period of study, 1512 stool samples were collected from schoolchildren (age group: 4-14 years, $n=1359$ ) attending one of 12 schools in Leganés (Madrid, Spain) and their siblings (age group: $1-16$ years, $n=153$ ). Only 10 participating children of the latter group had gastrointestinal symptoms the day of sampling and the previous week, but this was not found to be associated with any parasite, so children were still included in the study. Initial prevalence data and assessment of potential risk and/or protective factors associated with parasite infection were thoroughly described elsewhere [28]. Overall, G. duodenalis was the most prevalent enteric parasite found $(17.4 \%$, $95 \%$ confidence interval (CI): 15.5-19.4\%), followed by Blastocystis sp. (13.0\%, 95\% CI: 11.4-14.8\%), and Cryptosporidium spp. (0.9\%, 95\% CI: $0.5 \%-1.5 \%)$. Enterocytozoon bieneusi was not detected in any of the samples analysed. The prevalence rates of these pathogens in each participating school are summarized in Table 1. Estimates did not consider the clustered nature of the data, as this task was thoroughly conducted 
elsewhere [28]. The full dataset used to determine the prevalence rates and molecular diversity of G. duodenalis, Cryptosporidium spp., Blastocystis sp., and E. bieneusi of in this study is presented as a spreadsheet (Table S2).

Table 1. Prevalence (\%) and 95\% confidence intervals (CIs) of the enteric parasite species investigated in the present survey according to school of origin, Leganés, Madrid, 2017-2019.

\begin{tabular}{clcccc}
\hline School & $\boldsymbol{n}$ & Giardia duodenalis & $\begin{array}{c}\text { Cryptosporidium } \\
\text { spp. }\end{array}$ & $\begin{array}{c}\text { Blastocystis } \\
\text { sp. }\end{array}$ & $\begin{array}{c}\text { Enterocytozoon } \\
\text { bieneusi }\end{array}$ \\
\hline Global & 1512 & $17.4(15.5-19.4)$ & $0.9(0.5-1.5)$ & $13.0(11.4-14.8)$ & 0.0 (NA) \\
1 & 233 & $25.8(20.3-31.9)$ & $0.0(0.0-0.0)$ & $17.6(12.9-23.1)$ & 0.0 (NA) \\
2 & 134 & $26.1(18.9-34.4)$ & $0.0(0.0-0.0)$ & $11.9(7.0-18.7)$ & $0.0(\mathrm{NA})$ \\
3 & 124 & $20.2(13.5-28.3)$ & $0.8(0.0-4.4)$ & $9.7(5.1-16.3)$ & 0.0 (NA) \\
4 & 54 & $7.4(2.1-17.9)$ & $1.9(0.0-9.9)$ & $3.7(0.5-12.7)$ & 0.0 (NA) \\
5 & 65 & $1.5(0.0-8.3)$ & $0.0(0.0-0.0)$ & $13.8(6.5-24.7)$ & $0.0(\mathrm{NA})$ \\
6 & 144 & $9.0(4.9-14.9)$ & $0.0(0.0-0.0)$ & $13.2(8.1-19.8)$ & 0.0 (NA) \\
7 & 214 & $11.2(7.3-16.2)$ & $3.7(1.6-7.2)$ & $14.5(10.1-19.9)$ & 0.0 (NA) \\
8 & 73 & $11.0(4.9-20.5)$ & $1.4(0.0-7.4)$ & $15.1(7.8-25.4)$ & 0.0 (NA) \\
9 & 142 & $9.9(5.5-16.0)$ & $0.0(0.0-0.0)$ & $12.0(7.1-18.5)$ & 0.0 (NA) \\
10 & 136 & $30.9(23.2-39.4)$ & $1.5(0.2-5.2)$ & $11.8(6.9-18.4)$ & 0.0 (NA \\
11 & 128 & $19.5(13.1-27.5)$ & $0.0(0.0-0.0)$ & $10.2(5.5-16.7)$ & 0.0 (NA) \\
12 & 65 & $18.5(9.9-30.0)$ & $1.5(0.0-8.3)$ & $15.4(7.6-26.5)$ & 0.0 (NA) \\
\hline
\end{tabular}

NA: not applicable.

\subsection{Molecular Characterization of G. duodenalis Isolates}

A total of 263 DNA isolates tested positive for $G$. duodenalis by qPCR. Generated cycle threshold $(\mathrm{Ct})$ values ranged from $18.7-41.1$ (median: 33.9 ; 25th centile: $31.2 ; 75$ th centile: 35.3 ). Of these, $81 \%$ $(213 / 263)$ had qPCR Ct values $>30$. Based on previous molecular studies conducted by our research team in Spanish clinical populations [9,38], only DNA isolates with qPCR Ct values $\leq 30(n=50)$ were used for genotyping and sub-genotyping purposes.

Out of the 50 DNA isolates investigated, $42 \%$ (21/50), $18 \%$ (9/50), and $24 \%(12 / 50)$ were successfully amplified at the $g d h, b g$, and tpi loci, respectively. A total of 24 isolates were genotyped and/or sub-genotyped by any of the three markers. Multi-locus genotyping data were available for $12 \%(6 / 50)$ of the isolates characterised (Table 2). Sequence analyses revealed the presence of assemblages A (17\%, $4 / 24)$ and B $(83 \%, 20 / 24)$. All A sequences were assigned to the sub-assemblage AII of the parasite. Out of the $20 \mathrm{~B}$ sequences 19 were assigned to the sub-assemblage BIV and one corresponded to an ambiguous BIII/BIV result. No infections caused by mixed A+B or canine (C, D), feline (F), or ruminant (E) assemblages were detected. 
Table 2. Genotyping results of Giardia duodenalis sequences at the $g d h, b g$ and tpi loci obtained in the children population under study in Leganés, Madrid, 2017-2019.

\begin{tabular}{ccccc}
\hline Sample ID & $\boldsymbol{g d h}$ & $\boldsymbol{b g}$ & $\boldsymbol{t} \boldsymbol{p} \boldsymbol{i}$ & Assigned Genotype \\
\hline 125 & Negative & Negative & BIV & BIV \\
384 & BIV & Negative & Negative & BIV \\
507 & AII & AII & AII & AII \\
554 & BIV & B & BIV & BIV \\
566 & BIV & Negative & BIV & BIV \\
579 & BIV & Negative & BIV & BIV \\
737 & AII & AII & AII & AII \\
764 & Negative & B & Negative & B \\
823 & BIV & Negative & BIV & BIV \\
980 & BIV & Negative & Negative & BIV \\
991 & BIV & Negative & BIV & BIV \\
1030 & BIV & Negative & Negative & BIV \\
1435 & BIV & Negative & Negative & BIV \\
1459 & BIV & B & Negative & BIV \\
1662 & BIV & Negative & Negative & BIV \\
1721 & BIV & B & BIV & BIV \\
1777 & Negative & Negative & BIV & BIV \\
1784 & BIV & B & Negative & BIV \\
1821 & BIV & Negative & Negative & BIV \\
1904 & BIV & Negative & Negative & BIV \\
1991 & AII & AII & AII & AII \\
1997 & AII & Negative & Negative & AII \\
2041 & BIV & B & BIV & BIV \\
2172 & BIII/BIV & Negative & Negative & BIII/BIV \\
\hline
\end{tabular}

The diversity, frequency and main features of the G. duodenalis sequences generated at the $g d h$, $b g$, and tpi loci were summarized in Table 3. At the $g d h$ locus, three out of four AII sequences were identical to reference sequence L40510, with the remaining one differing from it by a single nucleotide polymorphism (SNP) at positions 269 (a double peak C/T). A much higher level of genetic diversity was observed within the 16 sequences unequivocally identified as sub-assemblage BIV, which differed by none to four SNPs with reference sequence L40508. Out of these BIV sequences, six were identical to L40508, eight contained ambiguous C/T sites (including heterozygous positions in the form of double peaks) at positions 183, 387, 396, and/or 423 of L40508, and two contained SNPs other than the above-mentioned. An additional sequence corresponded to a discordant BIII/BIV typing result (probably reflecting a BIII+BIV intra-assemblage mixed infection) differing by 12 SNPs (all of them corresponding to double peaks in the electropherogram) with L40508 (Table 3).

Similar results were observed with the sequences generated at the $b g$ locus. All three AII sequences showed $100 \%$ identity with the reference sequence AY072723, whereas the six sequences ascribed to the assemblage B varied from six to seven SNPs with reference sequence AY072727. Most of these B sequences included a typical pattern of mutations at positions 159 (G/A), $165(\mathrm{C} / \mathrm{T}), 309$ (C/T), $324(\mathrm{C} / \mathrm{T})$, $393(\mathrm{C} / \mathrm{T})$, and $471(\mathrm{~T} / \mathrm{C})$ with minor variations (Table 3). At the tpi locus two out of the three AII sequences identified were identical to reference sequence U57897, with the remaining one differing from it at positions $287(\mathrm{C} / \mathrm{G})$ and $291(\mathrm{~A} / \mathrm{W})$. Seven out of the nine BIV sequences showed 100\% identity with reference sequence AF069560. The remaining two sequences varied from it by one to three SNPs. BIV sequences generated at the tpi locus had comparatively lower genetic diversity than their counterparts did at the $g d h$ and $b g$ loci (Table 3). 
Table 3. Diversity, frequency, and molecular features of Giardia duodenalis sequences at the $g d h, b g$ and tpi loci obtained in the children population under study in Leganés, Madrid, 2017-2019. GenBank accession numbers are provided. Point mutations inducing amino acid substitutions are highlighted as superscript letters indicating the amino acid change.

\begin{tabular}{|c|c|c|c|c|c|c|c|}
\hline Locus & Assemblage & Sub-Assemblage & Isolates & Reference Sequence & Stretch & Single Nucleotide Polymorphisms & GenBank ID \\
\hline \multirow[t]{10}{*}{$g d h$} & A & AII & 3 & L40510 & $64-496$ & None & MN844134 \\
\hline & & & 1 & & $76-491$ & $\mathrm{~T} 269 \mathrm{Y}^{1}$ & MN844135 \\
\hline & $\mathrm{B}$ & BIV & 6 & L40508 & $76-491$ & None & MN844136 \\
\hline & & & 1 & & $76-496$ & C102Y, C105Y, C432Y, C435Y & MN844137 \\
\hline & & & 1 & & $78-485$ & $\mathrm{C} 126 \mathrm{Y}$ & MN844138 \\
\hline & & & 5 & & $76-441$ & T183C, T387C, C396T, C423T & MN844139 \\
\hline & & & 2 & & $76-482$ & T183Y, T387Y, C396Y, C423Y & MN844140 \\
\hline & & & 1 & & $76-496$ & T183Y, T387Y, C423Y & MN844141 \\
\hline & & & & & & C85Y2 ${ }^{2}, \mathrm{~T} 135 \mathrm{Y}, \mathrm{T} 183 \mathrm{Y}, \mathrm{G} 186 \mathrm{R}, \mathrm{C} 255 \mathrm{Y}$ & \\
\hline & & BIII/BIV & 1 & & $76-496$ & $\begin{array}{c}\text { C273Y, C345Y, T366Y, C372Y, T387Y, } \\
\text { A438R, G453R }\end{array}$ & MN844142 \\
\hline \multirow[t]{5}{*}{$b g$} & A & AII & 3 & AY072723 & $96-604$ & None & MN844143 \\
\hline & $\mathrm{B}$ & B & 3 & AY072727 & $93-593$ & $\begin{array}{c}\text { G159A, C165T, C309T, C324T, C393T, } \\
\text { T471C }\end{array}$ & MN844144 \\
\hline & & & 1 & & $102-590$ & $\begin{array}{c}\text { G159A, C165T, A265R }{ }^{3}, \text { C309T, } \\
\text { C324T, C393T, T471C }\end{array}$ & MN844145 \\
\hline & & & 1 & & $93-604$ & $\begin{array}{c}\text { G159A, C165T, C309T, C324T, } \\
\text { C352T }^{4}, \text { C393T, T471C }\end{array}$ & - \\
\hline & & & 1 & & $102-604$ & $\begin{array}{c}\text { G159A, C165T, C309T, C324T, C372T, } \\
\text { C393T, T471C }\end{array}$ & MN844146 \\
\hline \multirow[t]{5}{*}{$t p i$} & A & AII & 2 & U57897 & $282-751$ & None & MN844147 \\
\hline & & & 1 & & $276-805$ & C287G, A291W $W^{5}$ & MN844148 \\
\hline & $\mathrm{B}$ & BIV & 7 & AF069560 & $1-479$ & None & MN844149 \\
\hline & & & 1 & & $1-479$ & $\mathrm{~A} 201 \mathrm{R}^{6}$ & MN844150 \\
\hline & & & 1 & & $1-479$ & G305A, G425A, G426A ${ }^{7}$ & MN844151 \\
\hline
\end{tabular}

${ }^{1}$ If $\mathrm{C}, \mathrm{pM} 90 \mathrm{~T} ;{ }^{2}$ If T, pP29S; ${ }^{3}$ If G, pK89E; ${ }^{4}$ Stop codon; ${ }^{5}$ If T, pN95Y; ${ }^{6}$ If G, pT74A; ${ }^{7}$ pE143K; R: A/G; W: A/T; Y: C/T. 


\subsection{Molecular Characterization of Cryptosporidium spp. Isolates}

Analyses of the $14 \mathrm{ssu}$ rDNA sequences generated in the present study revealed the presence of two Cryptosporidium species circulating in the schoolchildren population investigated, including C. hominis $(71 \% ; 10 / 14)$ and C. parvum $(21 \% ; 3 / 14)$. An additional sample (1/14) was only identified at the genus level due to insufficient sequence quality (Table 4). A remarkable degree of genetic variability was observed among the 10 sequences assigned to $C$. hominis. Only five of them were identical to reference sequence AF108865, whereas the remaining five differed from it by one to four SNPs including substitutions, insertions, and the deletion of multiple nucleotides (Table 4). Two of the three sequences assigned to C. parvum revealed 98\% identity with reference sequence AF112571, although their quality was insufficient to ascertain with accuracy the presence/absence of SNPs. One of them was demonstrated to belong to the gp60 genotype family IId. The third sequence was identified as the 'bovine genotype' of C. parvum, also known as C. pestis by some authors [39] (Table 4).

Table 4. Diversity, frequency, and molecular features of Cryptosporidium spp. sequences at the ssu rRNA locus obtained in the children population under study in Leganés, Madrid, 2017-2019. GenBank accession numbers are provided.

\begin{tabular}{|c|c|c|c|c|c|}
\hline Species & $\begin{array}{l}\text { No. of } \\
\text { Isolates }\end{array}$ & $\begin{array}{l}\text { Reference } \\
\text { Sequence }\end{array}$ & Stretch & $\begin{array}{l}\text { Single Nucleotide } \\
\text { Polymorphisms }\end{array}$ & GenBank ID \\
\hline \multirow[t]{5}{*}{ C. hominis } & 5 & AF108865 & $572-994$ & None & MN836820 \\
\hline & 2 & & $606-938$ & C607T, C620T & MN836821 \\
\hline & 1 & & 589-985 & $\begin{array}{c}\text { C607T, C620T, } \\
\text { 697insT }^{1}, \text { G862T }\end{array}$ & MN836822 \\
\hline & 1 & & $536-949$ & $\begin{array}{c}\text { 695_697delTTT } \\
\text { T795C }\end{array}$ & MN836823 \\
\hline & 1 & & $687-952$ & A855G & MN836824 \\
\hline \multirow[t]{2}{*}{ C. parvum } & 2 & AF112571 & $603-877$ & Unknown ${ }^{3}$ & - \\
\hline & 1 & & 535-1025 & $\begin{array}{c}\text { A646G, T648C, } \\
\text { T649G, } \\
\text { 686-689delTAAT }{ }^{2} \\
\text { A691T, T910C }^{2}\end{array}$ & MN836825 \\
\hline Cryptosporidium spp. & 1 & - & - & - & - \\
\hline
\end{tabular}

\subsection{Molecular Characterization of Blastocystis sp. Isolates}

Out of the 197 isolates that tested positive for Blastocystis sp. by PCR, 82\% (162/197) were successfully subtyped. The remaining 35 isolates produced unreadable or poor-quality sequences typically associated to faint bands on agarose gels. Sequence analyses at the ssu rDNA (barcode region) gene of the parasite revealed the presence of five Blastocystis subtypes (ST), including ST1 (23\%; 37/162), ST2 (36\%; 59/162), ST3 (22\%; 35/162), ST4 (19\%; 30/162), and ST8 (1\%; 1/162) (Figure 2). Neither mixed infection involving different STs of the parasite nor infections caused by animal-specific ST10-ST17 were identified. A large genetic diversity was observed within ST2 (alleles 9, 10, 11, 12, 63, 69. 9+11, $10+12$, and 11+12) and ST3 (alleles 34, 36, 37, and 34+37). In contrast, only alleles 4 and 77 were observed within ST1, allele 42 within ST4, and allele 21 within ST8. Seven isolates (one in ST2 and six in ST3) could not be analysed at the allele level due to inaccurate or incomplete sequencing data (Figure 2). 


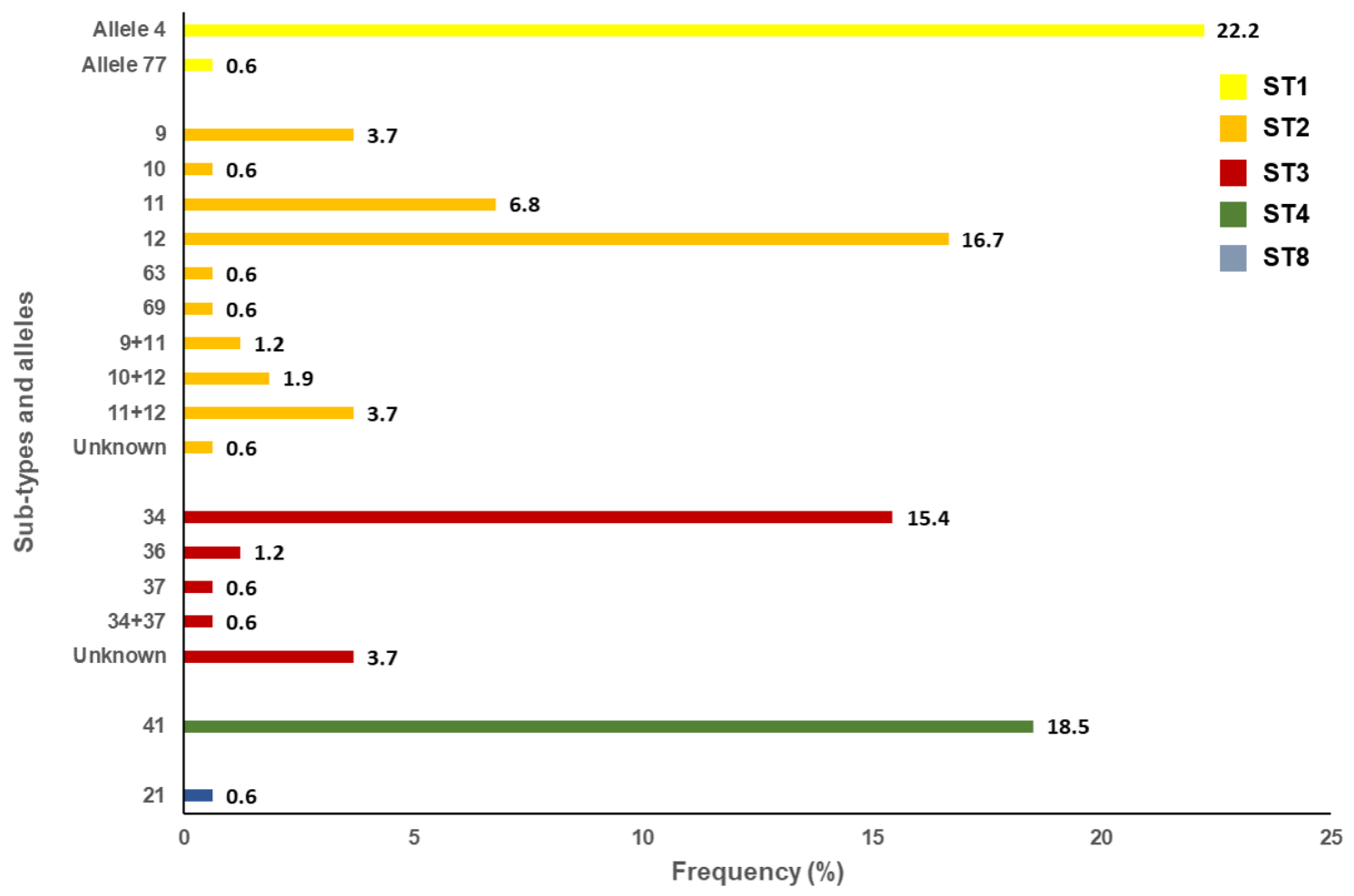

Figure 2. Diversity and frequency of Blastocystis subtypes and $18 \mathrm{~S}$ alleles identified in the schoolchildren population surveyed in the present study, Leganés, Madrid, 2017-2019.

No obvious clusters of parasite's species/genotypes were found according to the period of sampling or the sex, age group, and school of origin of the infected children, investigated in the present study.

\section{Discussion}

In the present study asymptomatic carriage of G. duodenalis (17\%), Blastocystis sp. (13\%), and Cryptosporidium spp. (0.9\%), but not E. bieneusi, was reported in apparently healthy schoolchildren in Leganés (Madrid); although unadjusted for clustering within schools, this is likely to be a fair estimate. This is the largest PCR and sequencing-based molecular survey conducted in asymptomatic individuals in Spain to date. Molecular data generated here were strengthened by the adoption of a multi-locus genotyping scheme for the molecular characterization of samples positive to G. duodenalis and Cryptosporidium spp.

In Spain, asymptomatic carriage of G. duodenalis has been previously reported in pre-schoolchildren (prevalence: $15-25 \%$ ) and schoolchildren (prevalence: 3-36\%) populations from rural and urban areas by conventional methods including light and immunofluorescence microscopy, ELISA for the detection of copro-antigens or rapid diagnostic tests [24,27,40]. Genotyping data are, however, far scarcer. Assemblage B (57\%) was the predominant G. duodenalis genetic variant detected in schoolchildren in the Álava province (northern Spain), followed by sub-assemblage AII (29\%) and AII+B mixed infections (14\%) [27]. BIV was the only sub-assemblage found in an ensuing survey conducted in the same region [41], and in children attending day care centres in the Madrid province, central Spain [40].

Giardia duodenalis prevalence (17\%) and genotyping (AII: 17\%; BIV: 79\%: BIII/BIV: $4 \%$ ) data presented here agreed well with the figures reported in the studies mentioned above, corroborating that assemblage B is 2-3 fold more prevalent than assemblage A in Spanish asymptomatic children populations. This is in sharp contrast with the results obtained in a recent molecular study conducted in G. duodenalis-positive outpatients of all ages attending hospital settings in 10 Spanish provinces showing that asymptomatic infection was more common in individuals with assemblage A than in those with assemblage B $(14 \%$ versus $1.5 \%, n=29)$ [42]. Strikingly, the G. duodenalis genotype 
frequencies shown here are very similar to those (AII: $15 \%$; BIV: $62 \%$ : BIII/BIV: $1.6 \%, n=124$ ), previously reported in patients with gastrointestinal complaints attending two major public hospitals in the Madrid province [38]. Not coincidentally, one of these hospitals was the University Hospital Severo Ochoa located in Leganés, whose catchment area was the very same investigated in the present study. It should be highlighted that these similitudes were also present at the nucleotide level, as $g d h$ and $b g$ sequence variants, generated in both studies, were observed at similar proportions. Overall, these data seem to indicate that essentially the same $G$. duodenalis genotypes circulate in asymptomatic carriers and symptomatic patients in Madrid province. Different assemblage A/B ratios have been identified in other Spanish regions [9,43], suggesting that the frequency and diversity of $G$. duodenalis genotypes may be geographically dependent.

In this study the presence of Cryptosporidium spp. was confirmed in a very low proportion $(<1 \%)$ of asymptomatic schoolchildren. Infection rates ranging from $1 \%$ to $10 \%$ have been previously estimated by non-molecular methods in children attending day care centres in Madrid [40] and the Salamanca province, western Spain [44], and in schoolchildren in the Álava province [27,41]. When available, molecular data in these surveys showed the presence of $C$. hominis only [27]. Our sequence analyses revealed that $C$. hominis was more prevalent than $C$. parvum $(71 \%$ versus $21 \%, n=14)$. Similar proportions have been previously described in clinical samples in different Spanish regions including Barcelona ( $88 \%$ versus 10\%, $n=69)$ [45], Galicia $(65 \%$ versus 34\%, $n=486)$ [46], La Rioja ( $82 \%$ versus $19 \%, n=81$ ) [9], and Madrid ( $82 \%$ versus $13 \%, n=108)$ [47]. These clinical studies also revealed that $\mathrm{Ib}$ (predominantly IbA10G2) and IIa (predominantly IIaA15G2R1) were the most frequent gp60 genotype families within C. hominis, and C. paroum, respectively. As in the case of G. duodenalis, these data indicate that $C$. hominis and $C$. parvum are circulating in both asymptomatic and symptomatic (clinical) populations in Spain. Absence of canine- (C. canis), feline- (C. felis), livestock (C. andersoni, C. bovis) or avian-specific (C. meleagridis) Cryptosporidium species seem to suggest that the spreading of the infection in the paediatric population under study is mainly through a human transmission cycle. Notably, C. hominis has also been more prevalently found than C. parvum in low- and medium-income countries with insufficient sanitation facilities [48].

The finding that $G$. duodenalis assemblages/sub-assemblages and Cryptosporidium species/genotype families are present at approximately equal proportions in both apparently healthy individuals and in subjects presenting with clinical manifestations in Spain has profound implications. It indicates that genotype does not suffice to explain the outcome of an infection by these pathogens, or the reason the very same pathogen can be virulent in one host, but avirulent in another. Microbial virulence has been considered as an emergent property, implying that the consequence of host-microbe interaction is inherently unpredictable [49]. In this regard, the term pathobiont has been initially coined to describe bacteria that colonize the gastrointestinal tract of individuals asymptomatically, but also have the potential to cause disease [50]. Mounting evidence demonstrates that the gut microbiota play a crucial role in host resistance against invading pathogens and indigenous pathobionts within the intestine through a number of mechanisms, including competitive metabolic interactions, localization to intestinal niches, and induction of host immune responses [51]. We hypothesize that G. duodenalis and Cryptosporidium spp., and very likely other enteric protists, may act as pathobionts under certain circumstances, and that their interaction with the host's microbiome and immune system may modulate their pathogenic responses. Definitively more research should be conducted in this interesting area of knowledge.

The Blastocystis sp. carriage rate estimated here (13\%) was well in the range of those $(8 \%-23 \%)$ previously reported by microscopy examination in preschool- and schoolchildren in Salamanca province [52]. Infection rates identified in earlier clinical studies in the country ranged from $3 \%-7 \%$ in symptomatic outpatients to $10 \%$ in HIV-infected children [53,54]. In Europe, ST1 to ST4 are the most common Blastocystis subtypes circulating in humans [55]. This is also the case of the present study, where ST2 $(36 \%)$, was the most prevalent genetic variant of the parasite, followed by ST1 $(23 \%)$, ST3 $(22 \%)$ and ST4 $(19 \%)$. The finding of ST $8(0.6 \%)$ can be considered as sporadic. These data indicate 
that the spreading of Blastocystis sp. in the paediatric population investigated is primarily through a human transmission cycle. Notably, the same results (although with a higher prevalence rate of $62 \%$ for ST2) have been documented in a community survey involving 179 individuals of all ages conducted in Álava province [26]. In both surveys, ST4 appeared to be considerably less represented (7.4-19\%) than ST1-ST3. Interestingly, ST4 has been identified in 94\% of Blastocystis mono-infected patients with diarrhoea in Valencia province, central-east Spain [23]. Similar findings have been reported in patients presenting with acute diarrhoea in Denmark [56] and in patients suffering from irritable bowel syndrome (IBS) and chronic diarrhoea in Italy [57]. Additionally, the relative frequency of ST4 seems to be higher than those for ST1-ST3 in patients with diarrhoea in hospital settings in Spain [58]. Taken together, these data suggest that ST4 could be more pathogenic than other Blastocystis STs. In support of this hypothesis, human acquisition of the ST4 lineage, very likely from wild rodents, has been proposed as a relatively recent evolutionary event [59]. Poor host adaptation may result, therefore, in increased parasite virulence. However, all these lines of evidence should still be considered with caution, as other investigations failed to demonstrate the pathogenic nature of ST4 [60,61]. Moreover, other research groups have proposed a link between ST1 and the aetiology of IBS [62], or between ST3 and gastrointestinal disorders, including diarrhoea [63].

It is well known that ST5 to ST9 are reported in humans only rarely [55]. In the present study ST8 was identified in a 10-year-old female reporting no contact with companion animals and no obvious risk factors for parasite infections. ST8 carriage has been previously documented almost exclusively in captive and free-living non-human primates in Central America [64,65], South America [66,67], and Europe [68]. Remarkably, an unexpectedly high prevalence of ST8 was seen among primate handlers in a zoological garden in UK, suggesting that zoonotic transmission of Blastocystis ST8 infections from primates to their handlers had occurred [68]. In our study, the source of infection by ST8 remains unclear.

Intriguingly, the microsporidia E. bieneusi was apparently absent in the surveyed, apparently healthy, schoolchildren population. In the only published study conducted by PCR in asymptomatic healthy individuals, E. bieneusi was detected in 6.0\% (23/382) of people of all age groups living in the Czech Republic [69]. In that survey only four out of the 23 detected cases of microsporidiosis by E. bieneusi occurred in children younger than 12 years of age. Taken together, these data are indicative of an age-related pattern of infection, with older individuals being more likely to harbour the parasite than younger ones. To date, E. bieneusi infections in Spain have been only identified in HIV/AIDS patients [54,70], transplant recipients [71], returning travellers [72], elderly people [73], and immunocompetent clinical populations [74].

This study presents some limitations. For instance, the different PCR formats (qPCR, nested PCR, direct PCR) used very likely differ in their diagnostic performances. In practical terms this means that the reported prevalence rates for certain parasites (e.g., Blastocystis sp.) may be underestimated. A relatively low proportion of $G$. duodenalis-positive samples were successfully genotyped at the assemblage and sub-assemblage level. This is a direct consequence of the high Ct values obtained by qPCR in most of the samples tested, a fact that compromised the diagnostic performance of the (single-copy gene) PCR methods used for genotyping purposes. The same is also true for the failure to determine $C$. hominis/C. parvum subtypes at the gp60 marker. These are somehow expected results, as asymptomatic carriage of intestinal parasites correlates well with light infections. Regarding Microsporidia, this study focuses exclusively on E. bieneusi. However, previous studies have revealed that microsporidia species, belonging to the Encephalitozoon genus, were frequently found in asymptomatic, apparently healthy individuals [69]. Investigating the presence of Encephalitozoon spp. should be investigated in future surveys.

\section{Conclusions}

This is the largest PCR-based epidemiological study investigating the genetic variability of G. duodenalis, Cryptosporidium spp., Blastocystis sp., and E. bieneusi in apparently healthy schoolchildren 
conducted in Spain to date. Molecular data presented here reveal important new insights in the epidemiology of these parasites. First, the observed frequency and diversity of species/genotypes are very similar to those previously identified in clinical samples. This finding strongly suggests that the genotypes of these pathogen are not determinant in tilting the balance between health and disease, and that other factors (e.g., co-infections, microbiome composition, and host immune status), very likely play a role in it. Second, anthroponotic transmission accounts for a large proportion of the detected cases, highlighting that improvement of personal hygiene practices (e.g., hand washing) is essential to minimize the risk of infection. Third, Blastocystis ST4 may represent a subtype of the parasite with higher pathogenic potential. Fourth, E. bieneusi does not represent a public health concern in healthy children.

Supplementary Materials: Supplementary materials can be found at http://www.mdpi.com/2076-2607/8/4/466/s1.

Author Contributions: Conceptualization, E.R.C. and D.C.; methodology, L.R., S.B., and D.C.; validation, S.B. and D.C.; formal analysis, L.R., S.B., N.Q.V., and D.C.; investigation, A.S.M., P.C.K., A.D., B.B., and M.H.-d.-M.; resources, S.B. and D.C..; data curation, S.B. and D.C.; writing-original draft preparation, S.B. and D.C.; writing-review and editing, A.S.M., S.B., and D.C.; visualization, E.R.C., S.B., and D.C.; supervision, S.B. and D.C.; project administration, D.C.; funding acquisition, D.C. All authors have read and agreed to the published version of the manuscript.

Funding: This research was funded by Health Institute Carlos III (ISCIII), Ministry of Science, Innovation and Universities, Spain, grant number PI16CIII/00024.

Acknowledgments: The authors are grateful to the participating children and their parents/legal guardians, and to school principals and teachers of the participating schools for their logistic assistance.

Conflicts of Interest: The authors declare no conflict of interest. The funders had no role in the design of the study; in the collection, analyses, or interpretation of data; in the writing of the manuscript, or in the decision to publish the results.

\section{References}

1. Torgerson, P.R.; Devleesschauwer, B.; Praet, N.; Speybroeck, N.; Willingham, A.L.; Kasuga, F.; Rokni, M.B.; Zhou, X.N.; Fèvre, E.M.; Sripa, B.; et al. World Health Organization estimates of the global and regional disease burden of 11 food-borne parasitic diseases, 2010: A data synthesis. PLoS Med. 2015, 12, e1001920. [CrossRef]

2. Li, W.; Feng, Y.; Santin, M. Host specificity of Enterocytozoon bieneusi and public health implications. Trends Parasitol. 2019, 35, 436-451. [CrossRef] [PubMed]

3. Efstratiou, A.; Ongerth, J.E.; Karanis, P. Waterborne transmission of protozoan parasites: Review of worldwide outbreaks-An update 2011-2016. Water Res. 2017, 114, 14-22. [CrossRef] [PubMed]

4. Ryan, U.; Hijjawi, N.; Feng, Y.; Xiao, L. Giardia: An under-reported foodborne parasite. Int. J. Parasitol. 2019, 49, 1-11. [CrossRef] [PubMed]

5. Certad, G.; Viscogliosi, E.; Chabé, M.; Cacciò, S.M. Pathogenic mechanisms of Cryptosporidium and Giardia. Trends Parasitol. 2017, 33, 561-576. [CrossRef] [PubMed]

6. Halliez, M.C.M.; Buret, A.G. Extra-intestinal and long term consequences of Giardia duodenalis infections. World J. Gastroenterol. 2013, 19, 8974-8985. [CrossRef]

7. Prado, M.S.; Cairncross, S.; Strina, A.; Barreto, M.L.; Oliveira-Assis, A.M.; Rego, S. Asymptomatic giardiasis and growth in young children; a longitudinal study in Salvador, Brazil. Parasitology 2005, 131, 51-56. [CrossRef] [PubMed]

8. Lengerich, E.J.; Addiss, D.G.; Juranek, D.D. Severe giardiasis in the United States. Clin. Infect. Dis. 1994, 18, 760-763. [CrossRef]

9. Azcona-Gutiérrez, J.M.; de Lucio, A.; Hernández-de-Mingo, M.; García-García, C.; Soria-Blanco, L.M.; Morales, L.; Aguilera, M.; Fuentes, I.; Carmena, D. Molecular diversity and frequency of the diarrheagenic enteric protozoan Giardia duodenalis and Cryptosporidium spp. in a hospital setting in Northern Spain. PLoS ONE 2017, 12, e0178575. [CrossRef]

10. Nourrisson, C.; Scanzi, J.; Pereira, B.; NkoudMongo, C.; Wawrzyniak, I.; Cian, A.; Viscogliosi, E.; Livrelli, V.; Delbac, F; Dapoigny, M.; et al. Blastocystis is associated with decrease of fecal microbiota protective bacteria: 
Comparative analysis between patients with irritable bowel syndrome and control subjects. PLoS ONE 2014, 9, e111868. [CrossRef]

11. Casero, R.D.; Mongi, F.; Sánchez, A.; Ramírez, J.D. Blastocystis and urticaria: Examination of subtypes and morphotypes in an unusual clinical manifestation. Acta Trop. 2015, 148, 156-161. [CrossRef] [PubMed]

12. WHO. Fighting Disease Fostering Development; The World Health Report; WHO: Geneva, Switzerland, 1996.

13. Khalil, I.A.; Troeger, C.; Rao, P.C.; Blacker, B.F.; Brown, A.; Brewer, T.G.; Colombara, D.V.; De Hostos, E.L.; Engmann, C.; Guerrant, R.L.; et al. Morbidity, mortality, and long-term consequences associated with diarrhoea from Cryptosporidium infection in children younger than 5 years: A meta-analyses study. Lancet Glob. Health 2018, 6, e758-e768. [CrossRef]

14. Andersen, L.O.; Stensvold, C.R. Blastocystis in health and disease: Are we moving from a clinical to a public health perspective? J. Clin. Microbiol. 2016, 54, 524-528. [CrossRef] [PubMed]

15. Lobo, M.L.; Xiao, L.; Antunes, F.; Matos, O. Microsporidia as emerging pathogens and the implication for public health: A 10-year study on HIV-positive and -negative patients. Int. J. Parasitol. 2012, 42, 197-205. [CrossRef]

16. Ryan, U.; Cacciò, S.M. Zoonotic potential of Giardia. Int. J. Parasitol. 2013, 43, 943-956. [CrossRef]

17. Ryan, U.; Fayer, R.; Xiao, L. Cryptosporidium species in humans and animals: Current understanding and research needs. Parasitology 2014, 141, 1667-1685. [CrossRef]

18. Stensvold, C.R.; Suresh, G.K.; Tan, K.S.W.; Thompson, R.C.A.; Traub, R.J.; Viscogliosi, E.; Yoshikawa, H.; Clark, C.G. Terminology for Blastocystis subtypes-A consensus. Trends Parasitol. 2007, 23, 93-96. [CrossRef]

19. Mintz, E.D.; Hudson-Wragg, M.; Mshar, P.; Cartter, M.L.; Hadler, J.L. Foodborne giardiasis in a corporate office setting. J. Infect. Dis. 1993, 167, 250-253. [CrossRef]

20. Salvador, F.; Sulleiro, E.; Sánchez-Montalvá, A.; Alonso, C.; Santos, J.; Fuentes, I.; Molina, I. Epidemiological and clinical profile of adult patients with Blastocystis sp. infection in Barcelona, Spain. Parasites Vectors 2016, 9, 548. [CrossRef]

21. Dubourg, A.; Xia, D.; Winpenny, J.P.; Al Naimi, S.; Bouzid, M.; Sexton, D.W.; Wastling, J.M.; Hunter, P.R.; Tyler, K.M. Giardia secretome highlights secreted tenascins as a key component of pathogenesis. Gigascience 2018, 7, 1-13. [CrossRef]

22. Xu, Z.; Guo, Y.; Roellig, D.M.; Feng, Y.; Xiao, L. Comparative analysis reveals conservation in genome organization among intestinal Cryptosporidium species and sequence divergence in potential secreted pathogenesis determinants among major human-infecting species. BMC Genomics 2019, 20, 406. [CrossRef] [PubMed]

23. Domínguez-Márquez, M.V.; Guna, R.; Muñoz, C.; Gómez-Muñoz, M.T.; Borrás, R. High prevalence of subtype 4 among isolates of Blastocystis hominis from symptomatic patients of a health district of Valencia (Spain). Parasitol. Res. 2009, 105, 949-955. [CrossRef] [PubMed]

24. Carmena, D.; Cardona, G.A.; Sánchez-Serrano, L.P. Current situation of Giardia infection in Spain: Implications for public health. World J. Clin. Infect. Dis. 2012, 2, 1-12.

25. Navarro-i-Martinez, L.; del Águila, C.; Bornay-Llinares, F.J. Cryptosporidium: A genus in revision. The situation in Spain. Enferm. Infecc. Microbiol. Clin. 2011, 29, 135-143. [CrossRef]

26. Paulos, S.; Köster, P.C.; de Lucio, A.; Hernández-de-Mingo, M.; Cardona, G.A.; Fernández-Crespo, J.C.; Stensvold, C.R.; Carmena, D. Occurrence and subtype distribution of Blastocystis sp. in humans, dogs and cats sharing household in northern Spain and assessment of zoonotic transmission risk. Zoonoses Public Health 2018, 65, 993-1002. [CrossRef]

27. Cardona, G.A.; Carabin, H.; Goñi, P.; Arriola, L.; Robinson, G.; Fernández-Crespo, J.C.; Clavel, A.; Chalmers, R.M.; Carmena, D. Identification and molecular characterization of Cryptosporidium and Giardia in children and cattle populations from the province of Álava, North of Spain. Sci. Total Environ. 2011, 412-413, 101-108. [CrossRef]

28. Reh, L.; Muadica, A.S.; Köster, P.C.; Balasegaram, S.; Verlander, N.Q.; Chércoles, E.R.; Carmena, D. Substantial prevalence of enteroparasites Cryptosporidium spp., Giardia duodenalis and Blastocystis sp. in asymptomatic schoolchildren in Madrid, Spain, November 2017 to June 2018. Eurosurveillance 2019, 24, 1900241. [CrossRef]

29. Verweij, J.J.; Schinkel, J.; Laeijendecker, D.; van Rooyen, M.A.; van Lieshout, L.; Polderman, A.M. Real-time PCR for the detection of Giardia lamblia. Mol. Cell. Probes 2003, 17, 223-225. [CrossRef]

30. Read, C.M.; Monis, P.T.; Thompson, R.C. Discrimination of all genotypes of Giardia duodenalis at the glutamate dehydrogenase locus using PCR-RFLP. Infect. Genet. Evol. 2004, 4, 125-130. [CrossRef] 
31. Lalle, M.; Pozio, E.; Capelli, G.; Bruschi, F.; Crotti, D.; Cacciò, S.M. Genetic heterogeneity at the beta-giardin locus among human and animal isolates of Giardia duodenalis and identification of potentially zoonotic subgenotypes. Int. J. Parasitol. 2005, 35, 207-213. [CrossRef]

32. Sulaiman, I.M.; Fayer, R.; Bern, C.; Gilman, R.H.; Trout, J.M.; Schantz, P.M.; Das, P.; Lal, A.A.; Xiao, L. Triose phosphate isomerase gene characterization and potential zoonotic transmission of Giardia duodenalis. Emerg. Infect. Dis. 2003, 9, 1444-1452. [CrossRef] [PubMed]

33. Tiangtip, R.; Jongwutiwes, S. Molecular analysis of Cryptosporidium species isolated from HIV-infected patients in Thailand. Trop. Med. Int. Health 2002, 7, 357-364. [CrossRef] [PubMed]

34. Feltus, D.C.; Giddings, C.W.; Schneck, B.L.; Monson, T.; Warshauer, D.; McEvoy, J.M. Evidence supporting zoonotic transmission of Cryptosporidium spp. in Wisconsin. J. Clin. Microbiol. 2006, 44, 4303-4308. [CrossRef] [PubMed]

35. Scicluna, S.M.; Tawari, B.; Clark, C.G. DNA barcoding of Blastocystis. Protist 2006, 157, 77-85. [CrossRef]

36. Buckholt, M.A.; Lee, J.H.; Tzipori, S. Prevalence of Enterocytozoon bieneusi in swine: An 18-month survey at a slaughterhouse in Massachusetts. Appl. Environ. Microbiol. 2002, 68, 2595-2599. [CrossRef]

37. Tamura, K.; Stecher, G.; Peterson, D.; Filipski, A.; Kumar, S. MEGA6: Molecular Evolutionary Genetics Analysis version 6.0. Mol. Biol. Evol. 2013, 30, 2725-2729. [CrossRef]

38. de Lucio, A.; Martínez-Ruiz, R.; Merino, F.J.; Bailo, B.; Aguilera, M.; Fuentes, I.; Carmena, D. Molecular genotyping of Giardia duodenalis isolates from symptomatic individuals attending two major public hospitals in Madrid, Spain. PLoS ONE. 2015, 10, e0143981. [CrossRef]

39. Slapeta, J. Cryptosporidium species found in cattle: A proposal for a new species. Trends Parasitol. 2006, 22, 469-474. [CrossRef]

40. Mateo, M.; Mateo, M.; Montoya, A.; Bailo, B.; Saugar, J.M.; Aguilera, M.; Fuentes, I.; Carmena, D. Detection and molecular characterization of Giardia duodenalis in children attending day care centers in Majadahonda, Madrid, Central Spain. Medicine 2014, 93, e75. [CrossRef]

41. De Lucio, A.; Bailo, B.; Aguilera, M.; Cardona, G.A.; Fernández-Crespo, J.C.; Carmena, D. No molecular epidemiological evidence supporting household transmission of zoonotic Giardia duodenalis and Cryptosporidium spp. from pet dogs and cats in the province of Álava, Northern Spain. Acta Trop. 2017, 170, 48-56. [CrossRef]

42. Wang, Y.; Gonzalez-Moreno, O.; Roellig, D.M.; Oliver, L.; Huguet, J.; Guo, Y.; Feng, Y.; Xiao, L. Epidemiological distribution of genotypes of Giardia duodenalis in humans in Spain. Parasites Vectors 2019, 12, 432. [CrossRef]

43. Gabín-García, L.B.; Bartolomé, C.; Abal-Fabeiro, J.L.; Méndez, S.; Llovo, J.; Maside, X. Strong genetic structure revealed by multilocus patterns of variation in Giardia duodenalis isolates of patients from Galicia (NW-Iberian Peninsula). Infect. Genet. Evol. 2017, 48, 131-141. [CrossRef] [PubMed]

44. Rodríguez-Hernández, J.; Canut-Blasco, A.; Martín-Sánchez, A.M. Seasonal prevalences of Cryptosporidium and Giardia infections in children attending day care centres in Salamanca (Spain) studied for a period of 15 months. Eur. J. Epidemiol. 1996, 12, 291-295. [CrossRef] [PubMed]

45. Segura, R.; Prim, N.; Montemayor, M.; Valls, M.E.; Muñoz, C. Predominant virulent IbA10G2 subtype of Cryptosporidium hominis in human isolates in Barcelona: A five-year study. PLoS ONE 2015, 10, e0121753. [CrossRef] [PubMed]

46. Abal-Fabeiro, J.L.; Maside, X.; Llovo, J.; Bartolomé, C. Aetiology and epidemiology of human cryptosporidiosis cases in Galicia (NW Spain), 2000-2008. Epidemiol. Infect. 2015, 143, 3022-3035. [CrossRef]

47. de Lucio, A.; Merino, F.J.; Martínez-Ruiz, R.; Bailo, B.; Aguilera, M.; Fuentes, I.; Carmena, D. Molecular genotyping and sub-genotyping of Cryptosporidium spp. isolates from symptomatic individuals attending two major public hospitals in Madrid, Spain. Infect. Genet. Evol. 2016, 37, 49-56. [CrossRef]

48. Squire, S.A.; Ryan, U. Cryptosporidium and Giardia in Africa: Current and future challenges. Parasites Vectors 2017, 10, 195. [CrossRef]

49. Casadevall, A.; Fang, F.C.; Pirofski, L.A. Microbial virulence as an emergent property: Consequences and opportunities. PLoS Pathog. 2011, 7, e1002136. [CrossRef]

50. Cerf-Bensussan, N.; Gaboriau-Routhiau, V. The immune system and the gut microbiota: Friends or foes? Nat. Rev. Immunol. 2010, 10, 735-744. [CrossRef]

51. Kamada, N.; Chen, G.Y.; Inohara, N.; Núñez, G. Control of pathogens and pathobionts by the gut microbiota. Nat. Immunol. 2013, 14, 685-690. [CrossRef] 
52. Martín-Sánchez, A.M.; Canut-Blasco, A.; Rodríguez-Hernández, J.; Montes-Martínez, I.; García-Rodríguez, J.A. Epidemiology and clinical significance of Blastocystis hominis in different population groups in Salamanca (Spain). Eur. J. Epidemiol. 1992, 8, 553-559. [CrossRef]

53. González-Moreno, O.; Domingo, L.; Teixidor, J.; Gracenea, M. Prevalence and associated factors of intestinal parasitisation: A cross-sectional study among outpatients with gastrointestinal symptoms in Catalonia, Spain. Parasitol. Res. 2011, 108, 87-93. [CrossRef] [PubMed]

54. Del Aguila, C.; Navajas, R.; Gurbindo, D.; Ramos, J.T.; Mellado, M.J.; Fenoy, S.; Muñoz Fernandez, M.A.; Subirats, M.; Ruiz, J.; Pieniazek, N.J. Microsporidiosis in HIV-positive children in Madrid (Spain). J. Eukaryot. Microbiol. 1997, 44, 84S-85S. [CrossRef] [PubMed]

55. Alfellani, M.A.; Stensvold, C.R.; Vidal-Lapiedra, A.; Onuoha, E.S.; Fagbenro-Beyioku, A.F.; Clark, C.G. Variable geographic distribution of Blastocystis subtypes and its potential implications. Acta Trop. 2013, 126, 11-18. [CrossRef] [PubMed]

56. Stensvold, C.R.; Christiansen, D.B.; Olsen, K.E.; Nielsen, H.V. Blastocystis sp. subtype 4 is common in Danish Blastocystis-positive patients presenting with acute diarrhea. Am. J. Trop. Med. Hyg. 2011, 84, 883-885. [CrossRef] [PubMed]

57. Mattiucci, S.; Crisafi, B.; Gabrielli, S.; Paoletti, M.; Cancrini, G. Molecular epidemiology and genetic diversity of Blastocystis infection in humans in Italy. Epidemiol. Infect. 2016, 144, 635-646. [CrossRef]

58. Köster, P.C.; Pérez-Ayala, A.; Molina, A.; Trelis, M.; Ruiz, G.; García-Hortelano, M.; Mellado, M.J.; Azcona Gutiérrez, J.M.; Martín, O.; Paulos, S.; et al. Variabilidad genética de Blastocystis sp. en pacientes atendidos en hospitales públicos españoles. In Proceedings of the XI Congress of the Spanish Society of Tropical Medicine and International Health, Ávila, Spain, 27-30 October 2019.

59. Stensvold, C.R. Thinking Blastocystis out of the box. Trends Parasitol. 2012, 28, 305. [CrossRef]

60. Meloni, D.; Sanciu, G.; Poirier, P.; El Alaoui, H.; Chabé, M.; Delhaes, L.; Dei-Cas, E.; Delbac, F.; Luigi Fiori, P.; Di Cave, D.; et al. Molecular subtyping of Blastocystis sp. isolates from symptomatic patients in Italy. Parasitol. Res. 2011, 109, 613-619. [CrossRef]

61. Seyer, A.; Karasartova, D.; Ruh, E.; Güreser, A.S.; Turgal, E.; Imir, T.; Taylan-Ozkan, A. Epidemiology and prevalence of Blastocystis spp. in North Cyprus. Am. J. Trop. Med. Hyg. 2017, 96, 1164-1170. [CrossRef]

62. Fouad, S.A.; Basyoni, M.M.; Fahmy, R.A.; Kobaisi, M.H. The pathogenic role of different Blastocystis hominis genotypes isolated from patients with irritable bowel syndrome. Arab. J. Gastroenterol. 2011, 12, 194-200. [CrossRef]

63. Tan, T.C.; Suresh, K.G.; Smith, H.V. Phenotypic and genotypic characterisation of Blastocystis hominis isolates implicates subtype 3 as a subtype with pathogenic potential. Parasitol. Res. 2008, 104, 85-93. [CrossRef] [PubMed]

64. Oliveira-Arbex, A.P.; David, É.B.; Tenório, M.D.S.; Cicchi, P.J.P.; Patti, M.; Coradi, S.T.; Lucheis, S.B.; Jim, J.; Guimarães, S. Diversity of Blastocystis subtypes in wild mammals from a zoo and two conservation units in southeastern Brazil. Infect. Genet. Evol. 2019, 78, 104053. [CrossRef] [PubMed]

65. Valença-Barbosa, C.; do Bomfim, T.C.B.; Teixeira, B.R.; Gentile, R.; Neto, S.F.D.C.; Magalhães, B.S.N.; Balthazar, D.A.; da Silva, F.A.; Biot, R.; d'Avila Levy, C.M.; et al. Molecular epidemiology of Blastocystis isolated from animals in the state of Rio de Janeiro, Brazil. PLoS ONE 2019, 14, e0210740. [CrossRef] [PubMed]

66. Villanueva-Garcia, C.; Gordillo-Chavez, E.J.; Lopez-Escamilla, E.; Rendon-Franco, E.; Muñoz-Garcia, C.I.; Gama, L.; Martinez-Flores, W.A.; Gonzalez-Rodriguez, N.; Romero-Valdovinos, M.; Diaz-Lopez, H.; et al. Clarifying the cryptic host specificity of Blastocystis spp. isolates from Alouatta palliata and A. pigra howler monkeys. PLoS ONE 2017, 12, e0169637. [CrossRef]

67. Helenbrook, W.D.; Shields, W.M.; Whipps, C.M. Characterization of Blastocystis species infection in humans and mantled howler monkeys, Alouatta palliata aequatorialis, living in close proximity to one another. Parasitol. Res. 2015, 114, 2517-2525. [CrossRef]

68. Stensvold, C.R.; Alfellani, M.A.; Nørskov-Lauritsen, S.; Prip, K.; Victory, E.L.; Maddox, C.; Nielsen, H.V.; Clark, C.G. Subtype distribution of Blastocystis isolates from synanthropic and zoo animals and identification of a new subtype. Int. J. Parasitol. 2009, 39, 473-479. [CrossRef]

69. Sak, B.; Brady, D.; Pelikánová, M.; Květoňová, D.; Rost, M.; Kostka, M.; Tolarová, V.; Hůzová, Z.; Kváč, M. Unapparent microsporidial infection among immunocompetent humans in the Czech Republic. J. Clin. Microbiol. 2011, 49, 1064-1070. [CrossRef] 
70. Del Aguila, C.; López-Velez, R.; Fenoy, S.; Turrientes, C.; Cobo, J.; Navajas, R.; Visvesvara, G.S.; Croppo, G.P.; Da Silva, A.J.; Pieniazek, N.J. Identification of Enterocytozoon bieneusi spores in respiratory samples from an AIDS patient with a 2-year history of intestinal microsporidiosis. J. Clin. Microbiol. 1997, 35, 1862-1866. [CrossRef]

71. Galván, A.L.; Sánchez, A.M.; Valentín, M.A.; Henriques-Gil, N.; Izquierdo, F.; Fenoy, S.; del Aguila, C. First cases of microsporidiosis in transplant recipients in Spain and review of the literature. J. Clin. Microbiol. 2011, 49, 1301-1306. [CrossRef]

72. López-Vélez, R.; Turrientes, M.C.; Garrón, C.; Montilla, P.; Navajas, R.; Fenoy, S.; del Aguila, C. Microsporidiosis in travelers with diarrhea from the tropics. J. Travel Med. 1999, 6, 223-227. [CrossRef]

73. Lores, B.; López-Miragaya, I.; Arias, C.; Fenoy, S.; Torres, J.; del Aguila, C. Intestinal microsporidiosis due to Enterocytozoon bieneusi in elderly human immunodeficiency virus-negative patients from Vigo, Spain. Clin. Infect. Dis. 2002, 34, 918-921. [CrossRef] [PubMed]

74. Abreu-Acosta, N.; Lorenzo-Morales, J.; Leal-Guio, Y.; Coronado-Álvarez, N.; Foronda, P.; Alcoba-Florez, J.; Izquierdo, F.; Batista-Díaz, N.; Del Aguila, C.; Valladares, B. Enterocytozoon bieneusi (Microsporidia) in clinical samples from immunocompetent individuals in Tenerife, Canary Islands, Spain. Trans. R. Soc. Trop. Med. Hyg. 2005, 99, 848-855. [CrossRef] [PubMed]

(C) 2020 by the authors. Licensee MDPI, Basel, Switzerland. This article is an open access article distributed under the terms and conditions of the Creative Commons Attribution (CC BY) license (http://creativecommons.org/licenses/by/4.0/). 